\title{
Atrazine and Picloram Adsorption in Organic Horizon Forest SAMPLES UNDER LABORATORY CONDITIONS ${ }^{1}$
}

\author{
Adsorção de Atrazina e Picloram em Amostras Florestais de Horizonte Orgânico
}

PINHO, A.P. ${ }^{2}$, MATOS, A.T. ${ }^{3}$, MORRIS, L.A. ${ }^{4}$ e COSTA, L.M. ${ }^{5}$

\begin{abstract}
Adsorption of two herbicides, atrazine and picloram, displaying different sorption characteristics, were evaluated for O (organic) horizon samples collected from SMZs (streamside management zones) in Piedmont (Ultisol) of Georgia, USA. Samples were randomly collected from within $5 \mathrm{SMZs}$ selected for a study of surface flow in field trials. The five SMZs represented five different slope classes, 2, 5, 10, 15 and 20\%. Results indicate that 0 horizons have the potential for sorbing atrazine from surface water moving through forested SMZs. Atrazine adsorption was nearly linear over a 24-hour period. Equilibrium adsorption, determined through 24-hour laboratory tests, resulted in a Freundlich coefficient of 67.5 for atrazine. For picloram, negative adsorption was observed in laboratory experiments. This seemed to be due to interference with ELISA analyses; however, this was not confirmed. The adsorption coefficient $(\mathrm{Kd})$ obtained for atrazine in 0 horizons was greater than it would have been expected for mineral soil (from 1 to 4). Picloram was not sorbed in 0 horizons at any significant degree. Although there is a significant potential for the direct adsorption of soluble forms of herbicides in SMZs, the actual value of this adsorption for protecting water is likely to be limited even for relatively strongly sorbed chemicals, such as atrazine, due to relatively slow uptake kinetics.
\end{abstract}

Keywords: herbicide retention, litter layer, sorption, surface runoff, solute transport

RESUMO - Este trabalho avaliou a adsorção de dois herbicidas - atrazina e picloram - com diferentes caracteristicas de sorção, em amostras florestais de horizonte orgânico (HO) coletadas em matas ciliares de manejo (MCM) localizadas em uma região de Piedmond (Ultisol), no estado da Geórgia, EUA. As amostras foram coletadas aleatoriamente dentro de cinco áreas de mata ciliar distintas, em classes de declividade de 2, 5, 10, 15 e 20\%, as quais foram selecionadas para desenvolver experimentos de campo sobre o transporte de herbicidas por escoamento superficial. Os resultados indicam que o HO apresenta potencial para adsorver atrazina na solução do escoamento superficial ao longo da mata ciliar. Em um periodo de 24 horas, o processo de adsorção de atrazina apresentou tendência linear. $O$ equilíbrio de adsorção, determinado em testes em laboratório com duração de 24 horas, pode ser expresso pela curva de Freundlich com coeficientef de 67,5 para a atrazina. O comportamento do picloram nos experimentos em laboratório foi diferente, apresentando tendência de adsorção negativa. Apesar de ainda não ser comprovado, esse fato pode ser devido à interferência do produto nas análises por Elisa. O coeficiente de adsorção (kd) da atrazina com HO foi maior do que o obtido para solos minerais (entre 1 e 4). Nenhum grau de significância foi obtido para adsorção de picloram aos HOs. Embora exista potencial significativo para a adsorção direta de formas solúveis de herbicidas em matas ciliares, a obtenção dos valores reais dessa adsorção, visando a proteção dos cursos d'água, é freqüentemente limitada, mesmo para aqueles produtos que apresentam forte sorção (atrazina), em razão do pouco tempo de contato entre o produto e o HO, para que a cinética ocorra.

Palavras-chave: retenção de herbicidas, serrapilheira, sorção, escoamento superficial, transporte de solutos.

Recebido para publicação em 18.10.2006 e na forma revisada em 27.2.2007.

Pesquisadora da Embrapa/Centro Nacional de Pesquisas em Gado de Corte, M.Sc., Universidade Federal de Mato Grosso do SUl, Departamento de Biologia, Caixa Postal 549, 79070-900 Campo Grande-MS, <alexandra@cnpgc.embrapa.br>. ${ }^{3}$ Professor Adjunto do Departamento de Engenharia Agrícola da Universidade Federal de Viçosa - DEA/UFV, 36570-000 Viçosa-MG, <atmatos@ufv.br>. ${ }^{4}$ Professor do Departamento de Recursos Florestais da Universidade da Geórgia, Athens, GA, EUA. ${ }^{5}$ Professor Titular do Departamento de Solos - DPS/UFV, <liovandomc@yahoo.com.br>. 


\section{INTRODUCTION}

Harvesting and preparation of recently harvested sites for planting has the potential to affect sediment and nutrient loading to aquatic ecosystems Intensive forest management that includes significant use of herbicides for competition control during stand establishment can contribute to water quality impacts by promoting areas of bare soils that produce overland flow during rainfall. Overland flow causes surface erosion and moves sediment, along with associated nutrients, fertilizers, and pesticides down the slope, potentially discharging these materials into streams.

Runoff generated by forest management is considered a non-point source from a regulatory standpoint and is controlled in most of the United States through voluntary Best Management Practices (BMPs). These BMPs provide guidelines for road construction, scheduling for harvest of adjacent areas of land, maintenance of dead trees for wildlife, petroleum handling and disposal and other activities. One BMP is to maintain a zone adjacent to streams within which harvesting and site disturbances are limited. These streamside management zones (SMZs) are considered of the most utmost important for the role they play in reducing the velocity of surface runoff and retention of sediment and associated nutrients. SMZs also reduce high water temperatures through shading and contribute to organic detritus to stream food webs. They also provide important wildlife habitat and have aesthetic value. Recently, Rivenbark (2002) evaluated the frequency and characteristics of ephemeral flow entering SMZs within clear-cut harvested and site prepared areas of the Georgia Piedmont. They found, on average, one location where water flowed through the $\mathrm{SMZ}$ for every 8 ha of harvested area.

Some studies have evaluated sediment retention in $\mathrm{SMZs}$; however, the fate and transport of colloidal clays, nutrients, and herbicides in dispersed sheet flow entering forested SMZs are not well understood. Phosphorus and most pesticides are strongly sorbed to colloidal clays that are less readily removed in SMZs than sand and silt-sized particles. Nevertheless, significant stream protection may be achieved by the filtering of colloidal material in forest $\mathrm{O}$ (organic) horizons and organic matter rich surface mineral horizons. In addition, adsorption of soluble forms of nutrients and pesticides to organic horizons can be achieved because of reduced water velocity and significant contact times.

Atrazine (2-chlor o-4-et hylla mi no-6isopropylamino-1,3,5-triazine), a hydrophobic and weak basic compound, is one of the most extensively used herbicides, worldwide. It has been intensively studied (Davis-Carter and Burgoa, 1993; Means and Wijayaratne, 1982; Sprague et al., 2000). It has been used for herbaceous weed control in young pine plantations alone and in combination with other herbicides. It is readily sorbed to soil particles, rather resistant to decomposition in soils, and has relatively low solubility (30 $\mathrm{mg} \mathrm{L}^{-1}$ ) resulting in low mobility and high persistence (Extension Toxicology Network, 1996).

Picloram (4-amino-3,5,6-trichloropicolinic acid) is an effective herbicide for control of broadleaved trees, woody perennial brush and vines. It is used both in mixes for preparation of harvested areas prior to planting and in directed application to broadleaved trees within pine plantations. This herbicide can adsorb on clay and organic matter, but at lower rates than atrazine. This, coupled with its high solubility in water $\left(430 \mathrm{mg} \mathrm{L}^{-1}\right)$, results in high mobility. Breakdown caused by sunlight and microorganisms in the soil are the main ways in which picloram degrades in the environment (Extension Toxicology Network, 1996). A list of chemical properties of other commonly used herbicides is shown in Table 1.

Many studies have been reported on the adsorption of herbicides on different soils and soil constituents (Barriuso et al., 1992; Gover, 1971; Huang et al., 1984; Seta and Karathanasis, 1997; Wauchope and Myers, 1985) but few studies have reported herbicide adsorption to forest soil organic horizons (Sundaram, 1995). Adsorption of herbicides within organic horizons of forested SMZs may play an important role in limiting herbicide movement from recently treated sites under conditions where high precipitation generates surface runoff. In this study, the adsorption 
rate of atrazine and picloram was evaluated on intact 0 horizon layers in batch experiments that simulate runoff conditions associated with a major storm event occurring just after herbicide application.

\section{MATERIAL AND METHODS}

Intact 0 horizon samples were collected within five Streamside Management Zones (SMZs) established adjacent to pine plantations located in the Oconee River watershed, in Clarke County, Putnam and Jasper Counties in Piedmont, northeastern Georgia. The five sites were representative of the range of conditions characteristic of Piedmont SMZs. Slopes classes were 1-2 \%, 5-6\%, 10-12\%, 15-17\% and 20-22\%. Vegetation species within all but the $1-2 \%$ slope were dominated by oaks. Leaves were the main component of the 0 horizon and thickness ranged from 0.25 to $19 \mathrm{~cm}$ with average of $5 \mathrm{~cm}$.

Three intact 0 horizon sample pairs were collected from each of the five sites in April and May of 2002 (30 samples in total). To collect samples, an $8.5 \mathrm{~cm}$ diameter metal cylinder was driven through the litter layer to the mineral soil surface. Samples were removed from the core and placed in plastic bags for return to the laboratory, where one of the pairs

Table 1 - Sorption characteristics of several herbicides

\begin{tabular}{|l|c|c|}
\hline \multicolumn{1}{|c|}{ Herbicide } & $\begin{array}{c}\text { Water solubility } \\
\left(\mathrm{mg} \mathrm{L}^{-1}\right)\end{array}$ & $K d^{1 /}$ \\
\hline 2,4 -D (acid) & 900.0 & 1.0 \\
\hline Alachlor & 242.0 & 3.7 \\
\hline Atrazine & 28.0 & 2.46 \\
\hline Carbofuran & 320.0 & 1.08 \\
\hline Ciazina & 40.0 & 2.53 \\
\hline Dicamba & $6,500.0$ & 0.10 \\
\hline Glyphosate & $12,000.0$ & 324 \\
\hline Hexazinone & $33,000.0$ & $0.59-10.8$ \\
\hline Metolachlor & 530.0 & $3-10$ \\
\hline Metribuzin & $1,050.0$ & 0.196 \\
\hline Metsulfuron-methyl & $4.6-9.0$ & $0.3-0.6$ \\
\hline Picloram & 430.0 & $\mathbf{N A}^{2 /}$ \\
\hline Triclopyr & 70.0 & 0.165 \\
\hline
\end{tabular}

Source: USDA (2000).

${ }^{1}$ Sorption coeficient with clay. ${ }^{2 / N A}=$ Not available. was dried at $65^{\circ} \mathrm{C}$ for moisture content determination. The second sample of each pair was utilized in the adsorption experiment. The mass of sample collected within the core area varied from 7 to $49 \mathrm{~g}$ with an average organic matter content of $720 \mathrm{~g} \mathrm{~kg}^{-1}$ (Table 2). An additional set of 9 samples was collected in January 2003 using the same methods used in additional adsorption experiments.

\section{4-hour equilibration experiment}

Adsorption experiments were based on a batch equilibration procedure (Gover, 1971) using six concentrations: 0, 12, 80, 147, 500 and $3324 \mu \mathrm{g} \mathrm{L}^{-1}$ of commercially formulated atrazine and $0,0.5,5.0,50$ and $500 \mu \mathrm{g} \mathrm{L}^{-1}$ of commercially formulated picloram. The weight average of 0 horizon for the 24 hour equilibrium experiments was $12.7 \mathrm{~g}$ varying from 10.9 to $13.9 \mathrm{~g}$. The experiment was carried out in $1 \mathrm{~L}$ beakers and the 0 horizon samples were held together with a $1 \mathrm{~mm}$ opening nylon mesh screen with nylon on the edges to maintain horizon structure. The initial mixture volume was $250 \mathrm{~mL}$. For each site, three samples were placed on an orbital shaker table adjusted to about 100 revolutions per minute. A $15 \mathrm{~mL}$ aliquot was sampled after 24 hours with a $20 \mathrm{~mL}$ syringe, placed in scintillation vials and stored at $4^{\circ} \mathrm{C}$ until analysis.

The adsorption isotherm to the 0 horizon was described by the Freundlich equation:

$$
x / m=K_{f} C e^{1 / n}
$$

where $x / m$ is the amount of herbicide ( $\mu g$ ) adsorbed per $\mathrm{mg}$ of $\mathrm{O}$ horizon, $\mathrm{Ce}$ is the equilibrium concentration $\left(\mathrm{mg} \mathrm{L}^{-1}\right)$, and $K_{f}$ and $1 / \mathrm{n}$ are empirical constants. The adsorption coefficient $\left(K_{d}\right)$ was obtained from the equation:

$$
K_{d}=\frac{C s}{C e}
$$

where Cs is the amount of herbicide (mg) adsorbed per $\mathrm{L}$ of solution.

\section{Kinetics experiment}

A second experiment was carried out in order to evaluate herbicide adsorption through time. In order to simulate real conditions of 
herbicide transport through surface runoff, soil particles were added to the experimental solution as colloids. Mixtures were prepared with atrazine $\left(55 \mu \mathrm{g} \mathrm{L}^{-1}\right)$, picloram $\left(35 \mu \mathrm{g} \mathrm{L}^{-1}\right)$ and commercially mined kaolin, uncleaned from iron-oxide coatings $\left(5 \mathrm{~g} \mathrm{~L}^{-1}\right)$. Experiments were conducted with three replicates for each site (slope). Initial mixture volume was $250 \mathrm{~mL}$. Samples were placed on an orbital shaker table at about 100 revolutions per minute. A $15 \mathrm{~mL}$ sample was collected with a $20 \mathrm{~mL}$ syringe with $22 \mu \mathrm{m}$ sterile nylon filter (Fisher Scientific, Norcross, GA) at $30 \mathrm{~s}, 60 \mathrm{~s}, 2 \mathrm{~min}, 10 \mathrm{~min}$, $1 \mathrm{hr}$ and $24 \mathrm{hr}$ after mixture was added. Samples were centrifuged at $3000 \mathrm{rpm}$ for 1 hour and the supernatant placed in scintillation vials and stored at $4{ }^{\circ} \mathrm{C}$ until analysis.

\section{Herbicide analyses}

Herbicide determination was made by enzyme-linked immunoassay (ELISA test) produced by Strategic Diagnostics Inc., Newark Delaware, with detection range of 0.04 to $5.0 \mu \mathrm{g} \mathrm{kg}^{-1}$ for atrazine and 0.87 to $20 \mu \mathrm{g} \mathrm{kg}^{-1}$ for picloram. These analyses were carried out at the University of Georgia Pesticide and Hazardous Waste Laboratory.

\section{Statistical analyses}

Adsorption mean and standard errors obtained at the equilibrium experiment were used to determine adsorption coefficients $\left(K_{f}\right.$ and $1 / \mathrm{n}$ ) for a Freundlich isotherm for each herbicide. The relationship between adsorption and time was evaluated using a regression approach. These analyses were acomplished using the statistical package of Statistica program using the non-linear estimation and the user-specified regression.

\section{RESULTS AND DISCUSSION}

Atrazine equilibrium adsorption isotherm to the 0 horizon was highly fit to the Freundlich equation (Figure 1) and the concentration for atrazine in solution decreased $72 \%$ after 24 hours (Table 3).

The same behavior was observed when the normalized mass (herbicide mass $/ 0$ horizon mass) was compared (Table 3). This relationship normalizes the adsorbed mass by the 0 horizon weight and helps to verify the adsorption effect alone. According to these results, after 24 hours, the atrazine mass was reduced 4 times the initial mass, while picloram increased 1.5 times the initial mass.

Picloram isotherm was not consistent once it indicated a negative adsorption (Table 3 ). Picloram data did not fit into the Freundlich equation, due to an increase of $170 \%$ in concentration after 24 hours. Although this behavior was reported before (Gover, 1971), this appeared to be due to interference with ELISA analyses and humic acid from 0 horizon samples; however, this was not confirmed.

The adjusted values are presented in Table 4 . The adsorption coefficient $\left(K_{d}\right)$ varied from 1.6 to 3.2 for atrazine and -0.9 to -2.1 for picloram. Due to inconsistent data observed for picloram, the coefficients were not shown.

Table 2 - Mean characteristics of organic horizons used in batch adsorption experiments

\begin{tabular}{|c|c|c|c|c|c|c|c|}
\hline \multirow{2}{*}{ Site } & $\begin{array}{c}\text { Wet mass } \\
\text { weight }\end{array}$ & Dry mass & $\begin{array}{c}\text { Field moisture } \\
\text { content }\end{array}$ & $\begin{array}{c}\text { Organic } \\
\text { matter mass }\end{array}$ & $\begin{array}{c}\text { Organic matter } \\
\text { fraction } \\
\text { material }\end{array}$ & Mineral mass & $\begin{array}{c}\text { Mineral } \\
\text { fraction }\end{array}$ \\
\cline { 2 - 8 } & \multicolumn{2}{|c|}{$(\mathrm{g})$} & $\left(\mathrm{g} \mathrm{g}^{-1}\right)$ & $(\mathrm{g})$ & $\left(\mathrm{g} \mathrm{kg}^{-1}\right)$ & $(\mathrm{g})$ & $\left(\mathrm{g} \mathrm{kg}^{-1}\right)$ \\
\hline 1 & $14.7 \pm 8.6$ & $10.1 \pm 5.4$ & $0.29 \pm 0.36$ & $8.7 \pm 5.7$ & $809 \pm 100$ & $1.5 \pm 0.5$ & $193 \pm 100$ \\
\hline 2 & $18.2 \pm 2.2$ & $11.5 \pm 1.3$ & $0.37 \pm 0.04$ & $8.8 \pm 1.1$ & $760 \pm 45$ & $2.8 \pm 0.6$ & $240 \pm 45$ \\
\hline 3 & $13.9 \pm 1.2$ & $9.7 \pm 1.0$ & $0.31 \pm 0.02$ & $6.9 \pm 1.9$ & $706 \pm 178$ & $2.7 \pm 1.4$ & $282 \pm 165$ \\
\hline 5 & $12.7 \pm 1.3$ & $7.1 \pm 0.4$ & $0.43 \pm 0.06$ & $5.6 \pm 0.8$ & $779 \pm 60$ & $1.5 \pm 0.4$ & $221 \pm 60$ \\
\hline Mean $\pm \mathrm{sd}$ & $37.1 \pm 8.3$ & $16.2 \pm 6.4$ & $0.58 \pm 0.07$ & $9.4 \pm 4.8$ & $553 \pm 82$ & $6.9 \pm 1.7$ & $447 \pm 82$ \\
\hline
\end{tabular}




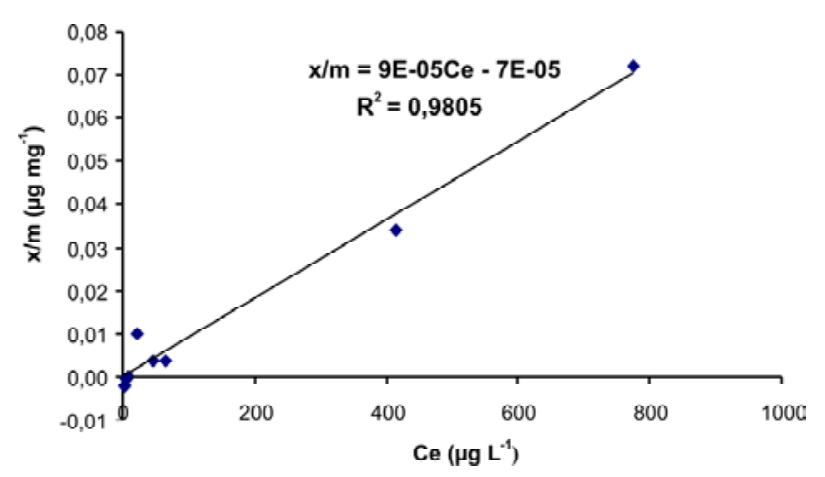

Figure 1 - Adsorption isotherm of atrazine to 0 horizon at equilibrium (24 hours). $x / m$ is the amount of herbicide $(\mu \mathrm{g})$ adsorbed per mg of 0 horizon.

Plots of the 24 hour adsorption kinetics experiment for atrazine and picloram are presented in Figures 2 and 3. Mean percentage of atrazine adsorption at $30 \mathrm{~s}, 60 \mathrm{~s}, 2 \mathrm{~min}$, $10 \mathrm{~min}$ and 1 hour was 5.2, 4.8, 7.7, 15.4 and $22.9 \%$, respectively. For picloram, the mean percentages of adsorption at $30 \mathrm{~s}, 60 \mathrm{~s}, 2 \mathrm{~min}$, $10 \mathrm{~min}$ and 1 hour were $0.04,0.5,-12.1$, 28.9 , and $-69.1 \%$, respectively. As indicated, after 24 hours the mass of atrazine decreased while the mass of picloram increased (Figures 2 and 3$)$.

The adsorption pattern of atrazine and picloram was fit to the Freundlich isotherm, which is in agreement with other studies (Gover, 1971; Sonon and Scwab, 1995). The Freundlich isotherm has been commonly used in studies of adsorption, and it is well suited to the adsorptive behavior of herbicide (Ebato et al., 2001). The atrazine isotherm resulted in high Freundlich constants (Table 4). As $K_{\mathrm{f}}$ indicates the strength or degree of the adsorption and $1 / \mathrm{n}$ indicates the curve slope (Sonon and Scwab, 1995), results show that atrazine has high adsorption to the 0 horizon. This behavior was expected since atrazine shows high adsorption to soil particles and low solubility. The high adsorption to the 0 horizon can be noted when comparing the atrazine $K_{f}$ value $(67.54)$ to the found for atrazine adsorption to whole soil particles (1.0 to 4.0) (Barriuso et al., 1992; Nakagawa et al., 1995; Seta and Karathanasis, 1997; Gomes et al., 2002). On the other hand, the amount of atrazine adsorbed by the amount of litter, represented by the normalized mass (Table 3) was lower in the 0 horizon $\left(1.01 \mu \mathrm{g} \mathrm{g}^{-1}\right)$ when compared to $6.35 \mu \mathrm{g} \mathrm{g}^{-1}$ obtained by (Huang et al., 1984) for clay particles.

The adsorption coefficient $\left(K_{d}\right)$ for atrazine was relatively high $2.4 \pm 0.8$. A small variation in the $K_{d}$ value occurred due to different sample weight used in the batch equilibrium experiment. If all conditions during batchequilibrium experiments are kept the same, the $K_{d}$ also has to be exactly the same. As we could not guarantee that all 0 horizon would have the same weight and conditions, the $K_{d}$ did not have the exact same value. Similar $K_{d}$ value $\left(2.48 \mathrm{~L} \mathrm{~kg}^{-1}\right)$ was found by Sprague et al. (2000) in adsorption with surface soil $(10 \mathrm{~cm}$ depth), which is also rich in organic material, and by the USDA (Table 1) in adsorption to clay particles.

After 24 hours, approximately $70 \%$ of the atrazine had been removed from the mixture. In contrast, no picloram was sorbed by the organic forest soil horizon. This was somewhat surprising in light of previous research that found a relationship between increasing organic matter content in mineral soils and increasing picloram adsorption (Hang et al. 1996). Results obtained in the present work are more similar to those of Gover (1971) who

Table 3 - Atrazine and picloram concentration and mass available in solution after 24 hours of adsorption to 0 horizon samples

\begin{tabular}{|l|c|c|c|c|}
\hline \multirow{2}{*}{} & Initial concentration & Final concentration & $\begin{array}{c}\text { Initial normalized } \\
\text { mass }^{1 /}\end{array}$ & $\begin{array}{c}\text { Initial normalized } \\
\text { mass }^{1 /}\end{array}$ \\
\cline { 2 - 5 } & \multicolumn{2}{|c|}{$\left(\mu \mathrm{g} \mathrm{L}^{-1}\right)$} & $1.3 \pm 0.5$ & $0.3 \pm 0.1$ \\
\hline Atrazine & $80.4 \pm 11.6$ & $22.0 \pm 4.9$ & $0.58 \pm 0.3$ & $0.92 \pm 0.3$ \\
\hline Picloram & $39.5 \pm 2.5$ & $105.3 \pm 31.3$ & $\left.\mathrm{~g} \mathrm{~g}^{-1}\right)$ \\
\hline
\end{tabular}

${ }^{4}$ Not estimatable. 
reported an increase in equilibrium solution picloram concentrations in batch experiments using clay minerals and cellulose powder and explained this apparent desorption as a result of adsorption of water from mixture coupled with a complete absence of picloram adsorption. Such an explanation is not reasonable for our experiment considering the large increases in solution concentration and the large solution mass to sample mass of our experiment. A second possible explanation is that we are observing desorption of previously applied picloram. Again, this seems unlikely.

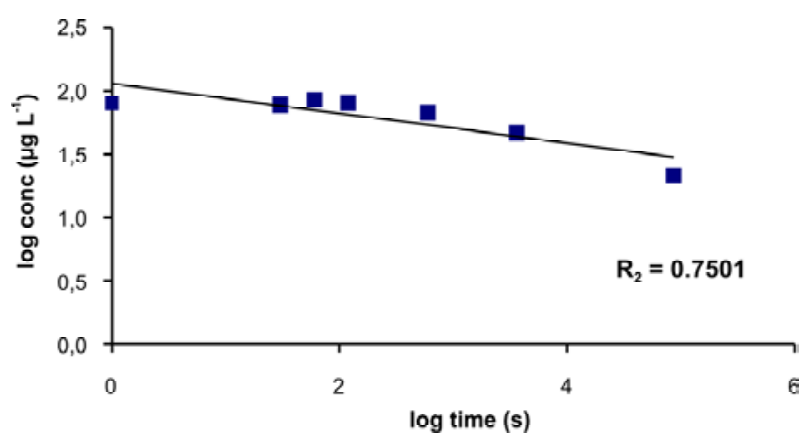

Figure 2 - Atrazine concentration through 24 hours adsorption to 0 horizon samples.

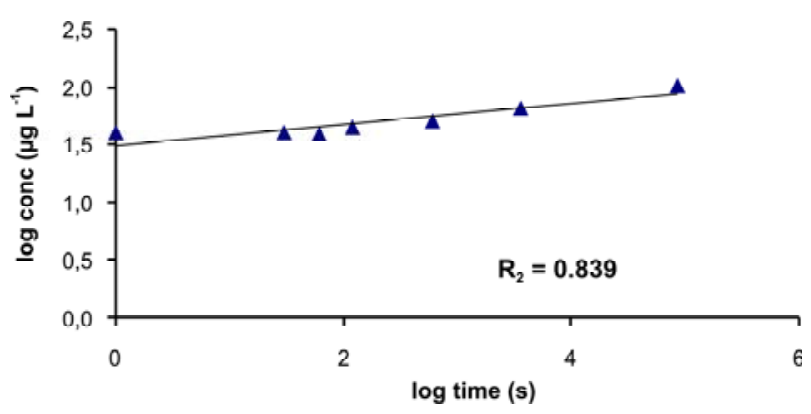

Figure 3 - Picloram concentration through 24 hours adsorption to 0 horizon samples.

Table 4 - Freundlich isotherm constants ( $K_{f}$ and $\left.1 / \mathrm{n}\right)$, adsorption coefficient $\left(K_{d}\right)$ and correlation coefficients for atrazine and picloram adsorption to 0 horizon

\begin{tabular}{|l|c|c|c|c|}
\hline \multirow{2}{*}{ Herbicide } & $K_{\mathrm{f}}$ & \multirow{2}{*}{$1 / n$} & $K_{d}$ & \multirow{2}{*}{$r^{2}$} \\
\cline { 2 - 2 } & $\left(\mathrm{L} \mathrm{kg}^{-1}\right)$ & & $\left(\mathrm{L} \mathrm{kg}^{-1}\right)$ & \\
\hline Atrazine & 67.54 & 0.7 & $2.4 \pm 0.8$ & 0.9 \\
\hline Picloram & $\mathrm{NE}$ & $\mathrm{NE}$ & $-1.5 \pm 0.6$ & $\mathrm{NE}$ \\
\hline
\end{tabular}

The half-life of picloram in mineral soil is reported to vary from 1 month under favorable environmental conditions to more than 4 years in arid regions (USDA, 2000). No data on the half-life of picloram in organic horizons of forest soils have been reported but it seems unlikely to greatly exceed this value. Detailed records of herbicide application were not available for the sites we sampled; however, the forest manager was confident that no applications had occurred within the past ten years. The most probable explanation is that the observed desorption is due to analytical interference, most likely resulting from organic acids solubilized from the organic materials during the course of the experiment. Although not measured, solutions collected at the end of the experiment were a reddish brown color indicative of soluble organic acids. Such acids contain a variety of functional groups that may have occupied sites on the assay kits, resulting in false positive values.

The flow velocities within the 0 horizon, obtained by experimental measures, range from 0.01 to $1.0 \mathrm{~m} \mathrm{~s}^{-1}$, thus, expected contact times for pesticide sorption within typical SMZs are in the order of a few seconds to, perhaps, 1 minute. We found that about $5 \%$ of the atrazine was retained after 30 s and about $15 \%$ was retained after 10 minutes. Thus, actual retention will be much lower than predicted by is otherms developed from 24-hour experiments. Furthermore, retention rates are low when compared to results of Wauchope and Myers (1985) who found that $50 \%$ of applied atrazine was adsorbed to well-mixed non-aggregated sediment slurries within 2 minutes and 90\% was adsorbed within 10 minutes. The lower rate of retention in intact 0 horizons may indicate that adsorption sites are partially protected by the structure of 0 horizon or by a degree of hydrophobicity. Additionally, adsorption sites may be created as organic acids are leached during the period of the experiment.

The establishment of Riparian Zones can protect water resources from pollutants (sediments, fertilizers and pesticides) both by retaining slowing runoff and retaining sediments and through sorption of soluble material within the 0 horizon. The degree of this retention is dependent on the time of 
contact between the surface flow mixture and the soil layer. As contact times for runoff are on the order of seconds, kinetics of sorption is important; 24-hour equilibrium experiments will overestimate retention. Results suggest that although there is a significant potential for the direct adsorption of soluble forms of herbicides in SMZs, the actual value of this adsorption for protecting water is likely to be limited even for relatively strongly sorbed chemicals such as atrazine, due to relatively slow uptake kinetics.

\section{LITERATURE CITED}

BARRIUSO, E.; BAER, U.; CALVET, R. Dissolved organic matter and adsorption-desorption of dimefuron, atrazine, and carbetamide by soils. J. Environ. Quality, v. 21, p. 359-367, 1992.

BINKLEY, D.; BROWN, T. C. Forest practices as nonpoint sources of pollution in North America. Water Res., v. 29, p. $729-740,1993$

DAVIS-CARTER, J. G.; BURGOA, B. Atrazine runoff and leaching losses from soil in tilted beds as influenced by three rates of lagoon effluent. J. Environ. Sci. Health B., v. 28, p. 1-18, 1993.

EBATO, M.; YONEBAYASHI, K.; KOSAKI, T. Predicting Freundlich adsorption isotherm of atrazine on japanese soils. Soil Sci. Plant Nutr., v. 47, p. 221-231, 2001.

EXTENSION TOXICOLOGY NETWORK. 1996.

Pesticide Information Profiles [Online]. Available by Cornell University, Oregon State University, University of Idaho, University of California at Davis.

GOMES, J.; DICK, D. P.; SOUZA, R. F. Sorção de atrazina em Cambissolo Húmico do Rio Grande do Sul sob vegetação nativa. R. Bras. Ci. Solo, v. 26, p. 521-528, 2002.

GOVER, R. Adsorption of picloram by soil colloids and various other adsorbents. Weed Sci., v. 19, p. 417-418, 1971.
HANG, S. B.; FERREIRO, E. A.; BUSSETTI, S. G. Picloram adsorption-desorption by soil and other pure adsorbents. Eur. Soil Sci., v. 29, p. 775-782, 1996.

HUANG, P. M.; GROVER, R.; MCKERCHER, R. B. Components and particle size fractions involved in atrazine adsorption by soils. Soil Sci., v. 138, p. 20-24, 1984.

MEANS, J. C.; WIJAYARATNE, R. Role of natural colloids in the transport of hydrophobic pollutants. Science, v. 25, p. 968-970, 1982.

NAKAGAWA, L. E. et al. Comportamento da atrazina em solos brasileiros em condições de laboratório. Pesq. Agropec. Bras., v. 30, p. 471-476, 1995.

RIVENBARK, L. Headwater stream management issues in Georgia: streamside management zone effectiveness and small trout stream hydrologic characterization. 2002. $83 \mathrm{f}$. Thesis (Magister Science) - University of Georgia, Athens, 2002.

SETA, A. K.; KARATHANASIS, A. D. Atrazine adsorption by soil colloids and co-transport through subsurface environments. Soil Sci. Soc. Am. J., v. 61, p. 612-617, 1997.

SONON, L. S.; SCWAB, A. P. Adsorption characteristics of atrazine and alachlor in Kansas soils. Weed Sci., v. 43, p. 461-466, 1995.

SPRAGUE, L. A. et al. Atrazine adsorption and colloidfacilitated transport through the unsaturated zone. J. Environ. Quality, v. 29, p. 1632-1641, 2000.

SUNDARAM, K. M. S. Persistence and fate of tebufenozide (RH-5992) insecticide in terrestrial microcosms of a forest environment following spray application of two mimic formulations. J. Environ. Sci. Health, v. B30, p. 321-358, 1995.

USDA. Forest Service Herbicide information profile: Picloram, Pacific Northewest Region: 21. 2000.

WAUCHOPE, R. D.; MYERS, R. S. Adsorption-desorption kinetics of atrazine and linuron in freshwater-sediment aqueous slurries. J. Environ. Quality, v. 14, p. 132-136, 1985. 